\title{
Analysis of Factors Determinant of Stunting in Children Ages 2-5 Years in the Working Area of Pustu Kedunglengkong at Dlanggu Public Health Center Mojokerto
}

Rita Sugihati ${ }^{1}$,
Nur Wijayanti ${ }^{2}$,
Indasah $^{2}$
Magister of Health Study
${ }^{1}$ Program of Institut Ilmu Kesehatan
STRADA Indonesia
${ }^{2}$ Lecturer of Institut Ilmu
Kesehatan STRADA Indonesia
Email:
ritasugi@gmail.com

Received : October 12, 2019

Accepted : February 13, 2020

Published: May 12, 2020

\begin{abstract}
Nutritional problems are still a trend at the moment is the problem of stunting (short). Stunting (short) in Indonesia is a problem that is often overlooked because it is considered not to affect their children's future. Most of the community does not dispute the slow growth of the child's height when a toddler. While the child is still healthy and frisky, stunting (short) is not a problem that needs to be addressed. Design research is crossectional approach analytic. The research of the variable intake of food, infection, disease history of availability of food, nutrition and parenting as the independent variable and the dependent variable as a stunting Incident. Population research namely the entire toddler at toddler 397 Pustu Kedunglengkong as much as 2-5 years of age. Samples taken by random sampling technique as much as 101 respondents. Data collected by questionnaire instrument and processed by using coding, editing, tabulating and scoring as well as tested with logistic regression test. The results of this research show that partially or alone - its own independent variable may affect the occurrence of the dependent variables because the value significance $<0.05$. Independent variable affect simultaneously or together can affect the incidence of stunting, indicated by the value of the overall percentage of 78 meaning independent variable can affect both variables of $78 \%$. The results of this research show the value of the most high is wald of infectious diseases. So it can be declared of infectious diseases is the dominant factor affecting the occurrence of stunting. Because the children often experience the infectious disease then it will decrease the frequency of child food and nutrients are not absorbed optimally so that it can menggangun the growth of the child.
\end{abstract}

Keywords: Food intake, history of Infectious diseases, the availability of food, parenting, the incidence of stunting, children ages 2-5 years

\section{cc) (†) ()}

This is an open-acces article distributed under the terms of the Creative Commons Attribution-ShareAlike 4.0 International License. 


\section{INTRODUCTION}

Nutritional problem is a problem in the cycle of life, from pregnancy, babies, toddlers, adolescents, up to the elderly. Nutritional problems can occur in all age groups, even the nutritional problems at a certain age group will impact on nutritional status in the period of the next life cycle (intergenerational impact) (Kemenkes, 2012). Nutritional problems are still a trend at the moment is the problem of stunting (short). Stunting (short) in Indonesia is a problem that is often overlooked because it is considered not to affect their children's future. Most of the community does not dispute the slow growth of the child's height when a toddler. While the child is still healthy and frisky, stunting (short) is not a problem that needs to be addressed (Nasution, 2013).

Height growth and developmental changes occurred in the first 3 years of age. serebellum brain that coordinates the motion of the motor is the most vulnerable part damaged during the 3 first years of the life of a toddler, so malnutrition in early life the child will inhibit the development of motor skills. In children who experience stunting will have low motor activity (Wani Y, 2010). The existence of the attitude of parents still less care on nutritional needs of toddlers occurs due to lack of knowledge of mothers about the importance of the issue and its impact on Toddler Nutrition toddler (Juliyanti, 2014). Stunting is a poor predictor of the quality of human resources will further affect the development potential of Nations (Unicef, 2013).

According to the WHO Data year 2017 mennunjukkan that one in four children under age 5 had a late growth or stunting. The number of stunting the largest found in Sub-Saharan Africa as much as 90 per cent of the toddler (WHO, 2018). Based on the results of the radar of nutritional Status (PSG) 2017 stunting prevalence of infants aged under five years (Toddlers) East Nusa Tenggara (NTT) reached $40.3 \%$. The figure is the highest compared to other provinces and also above the national prevalence of stunting of $29.6 \%$. The prevalence of stunting in NTT consists of a baby with very short category $18 \%$ and $22.3 \%$ short. While the province with the lowest prevalence of stunting Toddler is Bali, i.e. only reached $19.1 \%$. The figure consists of a toddler with a category of very short short $14.2 \%$ and $4.9 \%$. The result PSG last year noted that the prevalence of a toddler who suffered a stunting of $29.6 \%$, higher than the previous year only $27.5 \%$. But in 2019 , stunting targeted down to $28 \%$ by 2019 . Stunting is a problem of chronic malnutrition due to the intake of a nutrient is lacking so that baby's height under standard according to his age. According to the World Health Organization maximum limit of stunting the baby is $20 \%$. This means that the stunting Toddler in Indonesia currently still above the limit of tolerance set by the World Health Organization.

Prevalence of stunting 2017 26.7\% of East Java and East Java province is included in the rankings to 14 the number of sufferers with stunting (Kemenkes, 2018). Based on data from Clinics Dlanggu obtained data the number of toddlers through August 2018 as much of 4138 toddlers with the number of sufferers in Stunting Clinic Dlanggu as much as $25.2 \%$ of the total by the number of toddlers, toddlers are stunting in megnalami Pustu Kedunglengkong. The number of toddlers at a Pustu Kedunglengkong in August, as many as the number of toddlers and babies 861 stunting as much as 210 fives (24.4\%). The number of babies in the village of Tumapel as much as 142 toddlers with number of stunting as much as 51 fives (35.9\%), the number of babies in the village of Sumberkarang as many as 257 toddlers with number of stunting as much as 67 fives $(26.1 \%)$, the number of babies in the village of Kedunglengkong as much as 162 a toddler with a number of stunting as much as 23 toddler (14.2\%) and in the village of Randugenengan as many as 300 babies by the sum of stunting as much as 69 toddler $(23 \%)$.

Early observations of researchers against the 10 mother toddler 6 toddler mom data obtained $(60 \%)$ said they still do not know how to give good nutrition on a toddler so that does not happen, problems related to the nutrition family income so that the mother could not 
provide food that filled the whole nutritional elements in toddlers. Whereas on 4 mother toddler $(40 \%)$ said they were trying to keep meet the nutritional needs of toddlers in accordance with their age so that the mother can prevent the occurrence of a nutritional problem.

Stunting or short is one indicator of clinical nutrition who can give an overview of the social disorder of the overall economy in the past and as a result a further manifestation of the high number of low birth weight and less nutrition in infancy and lack of achievement growth improvement (catchup growth) was perfect during the next. Stunting growth retardation also means linear with the deficit on a length of $2 \mathrm{z}$-score < or more on the indicator length according to age more according to the raw growth reference (the WHO 2015). Factors affecting the occurrence of stunting in children toddlers who are in rural and urban areas is the mother's education, family income, mother's knowledge about nutrition, parenting, exclusive breast feeding, age awarding MP-ASI, the level of adequacy of zink, the level of adequacy of iron, a history of infectious diseases as well as genetic factors of elderly mother's employment status, however, the number of family members, immunization status, the level of energy sufficiency, and the status of LOW BIRTH WEIGHT can also be a factor in the originator affect the occurrence of stunting (Aridiyah, 2015).

Stunting that occurs at the time a child is a risk factor for increased mortality, cognitive ability and motor development are low and functions of the body isn't balanced, low motor development and functions - not body function balanced. Stunting on toddler needs to be special attention because it could hinder the physical and mental development of the child. Stunting related to an increased risk of pain and death as well as terhambatnya growth motor ability and mental (Purwadini, 2013)

\section{METHODS}

Design of this research was analytic with crossectional approach. This research variables are food intake, history of infectious diseases, the availability of food, parenting nutrition as the independent variable and the dependent variable as a stunting Incident. Population research all of 2-5 years children at Pustu Kedunglengkong as much as 397 children's. Samples taken by random sampling technique as much as 101 respondents. Data collected by questionnaire instrument and processed by using coding, editing, tabulating and scoring as well as tested with logistic regression test. Data collection is done by distributing questionnaires at 2-5 years after the toddler's mother directly. Research will be conducted in September - November 2018.

Data analysis in this study are:

1) The assessment of food intake

Assessment of dietary intake was assessed with a food recall cheklist sheet 24 hours as follows:

a) low: $<70 \%$ AKG

b) high $>70 \% \mathrm{AKG}$

2) Infection History Assessment

Infection history assessment done by sheets of interview with the following criteria:

a) Ever

b) Never

3) Assessment of Parenting

Assessment of each reserved if true $=1$ and $=0$ criteria parenting were classified according to the according to the Interview And the Goddess (2011) as follows:

a) Good in a score $76-100 \%$

b) Enough in score $56-75 \%$

c) Less good if the score $56<\%$

4) Assessment of food security

Customized food security assessment with a score of food Pattern of hope (PPH) with the following criteria:

a) Less: Score AKE < score Maximum

b) Good: score AKE = Maximum Score 


\section{RESULT}

1. Analysis of Bivariat between food intake, infectious diseases, Food Availability and Parenting With the incidence of Stunting

Table 4.1 Spearman rho test results between food intake, infectious diseases, Food Availability and Parenting with stunting on toddlers ages 2-5 years in the region Kedunglengkong Dlanggu Clinics Pustu Mojokerto October 2018 ( $n=100)$

\begin{tabular}{cccc}
\hline Independen Variable & Dependen variable & Corelation Coeffisien & Signification \\
\hline Food Intake & Stunting Incidence & 0,275 & 0,006 \\
\hline Infectious diseases & Stunting Incidence & 0,524 & 0,000 \\
\hline Food Availability & Stunting Incidence & 0,511 & 0,000 \\
\hline Parenting & Stunting Incidence & 0,468 & 0,000 \\
\hline
\end{tabular}

Based on the results in table 4.1 shows that test result spearman rho between food intake, with an incidence of stunting shows the significance value $=0.006<0.05$ so that $\mathrm{H} 1$ accepted it means there is a connection between food intake with incidence stunting.

A history of infection with stunting incident shows the significance value $=0.000<0.05$ so that $\mathrm{H} 1$ accepted it's means there is a connection between a history of infection with stunting incident.

Food availability with stunting incident shows the significance value $=0.000<0.05$ so that $\mathrm{H} 1$ accepted it's means there is a relationship between food availability with stunting incident.

Parenting nutrition with stunting incident shows the significance value $=0.00<0.05$ so that $\mathrm{H} 1$ accepted it's means there is a connection between nutrition parenting with stunting incident.

\section{Multivariat Analysis}

1) Partial Anaylysis

Table 4.2 Logistic regression analysis of partially between food intake, History of infectious diseases, food availability and parenting against Gen. stunting on toddlers ages 2-5 years in the region Kedunglengkong Dlanggu Clinics Pustu Mojokerto in October $2018(n=100)$

\begin{tabular}{|c|c|c|c|c|c|c|}
\hline Variable & B & S.E & Wald & df & Sig & $\operatorname{EXp}(B)$ \\
\hline Food Intake & 1.364 & .580 & 5.525 & 1 & .019 & 3.911 \\
\hline Infectious diseases & 1.762 & .579 & 9.253 & 1 & .002 & 5.821 \\
\hline Food Availability & 1.594 & .599 & 7.073 & 1 & .008 & 4.922 \\
\hline Parenting & 1.093 & .471 & 5.377 & 1 & .020 & 2.982 \\
\hline
\end{tabular}

Based on the results in table 4.2 shows partially or each independent variable influences the incidence of stunting, indicated by the value of the wald on food intake amounted to 5.525 with significance and value of 0.019 wald of infectious diseases of significance with 0.0029 .253 , wald on the availability of food of 7.073 with significance and value of 0.008 wald on parenting of 5.377 with significance of 0.020 . The results of this research show that partially or alone - its own independent variable may affect the occurrence of the dependent variables because the value significance $<0.05$.

\section{2) Simultaneously anaylisis}

Tabel 4.3 Logistic regression analysis of simultaneously between food intake, History of infectious diseases, food availability and parenting against Gen. stunting on toddlers ages 2-5 years in the region Kedunglengkong Dlanggu Clinics Pustu Mojokerto in October 2018 (n = 100)

\begin{tabular}{ccccc}
\hline & \multicolumn{4}{c}{ Classification Table } \\
& & \multicolumn{2}{c}{ Stunting Incidence } & \multirow{2}{*}{ Stunting Incidence } \\
\cline { 2 - 4 } & & Stunting & Normal & \\
\hline \multirow{2}{*}{ Stunting Incidence } & Stunting & 26 & 13 & 66.7 \\
\cline { 2 - 4 } & Normal & 9 & 52 & 85.2 \\
\hline \multicolumn{2}{c}{ Overall Percentage } & & & 78.0 \\
\hline
\end{tabular}


Based on the results in table 4.3 indicates that independent variable affect simultaneously or together can affect the incidence of stunting, indicated by the value of the overall percentage of 78 meaning independent variable can affect both variables of $78 \%$. The results of this research show that simultaneously or together independent variables can affect the occurrence of the dependent variable.

\section{DISCUSSION}

A. Analyse the influence of food intake Against the incidence of Stunting in Children Ages 2-5 years in the working area Pustu Kedung Lengkong Clinics Dlanggu Mojokerto

Based on the results of research on a given food intake on toddlers showed that most of the dietary intake of nutrients are high fives as many as 58 respondents $(58 \%)$. Food intake which belonged to children aged 2-5 years on the research respondents there were 35 children (35\%) have an intake of energy in accordance with the age of the child, namely between 1200-1400 kilo calories per day, 23 children (23\%) have an energy intake of 1000-1100 kilos calories per day, 42 children (42\%) are included in the category of less energy intake between 800-900 kilo calories per day. Based on the test results of the spearman rho between food intake, with an incidence of stunting shows the significance value $=0.006<0.05$ so that $\mathrm{H} 1$ accepted it's means there is a connection between food intake with incidence of stunting.

Nutrients (nutrients) is an important part of health and growth. Good nutrition is associated with increased health of infants, children, and mother, a strong immune system, pregnancy and birth are safe, low risk to disease is not contagious like diabetes and heart disease, and a longer lifespan (WHO, 2011). The nutritional intake of the adekuat is indispensable for the growth and development of the body of a toddler. This critical period is the period of time the toddler will experience the growing swell and grow a Chase. A toddler who suffered malnutrition before can still be improved with a good intake so it can do a growing League in accordance with its development. But when its intervention late toddler won't be able to pursue its growth called the delay failed to grow (Bappenas RI, 2013). Bad food quality includes the quality of the micronutrient is bad, the lack of diversity and food intake were sourced from animal food, the content is not nutritious, and low energy content in complementary foods. The practice of feeding inadequate, including a rare feeding, feeding that is not adekuat during and after the pain, the consistency of the food which is too light, the quantity of food is insufficient, the feeding is not berespon. Evidence shows the diversity of a more varied diet and consumption of foods from animal sources related to the improvement of linear growth. The latest analysis shows that households who apply a diverse diet, including a diet enriched with nutritional complements, will increase the nutritional intake and reduce the risk of stunting (Sik Asik, 2011).

According to researchers given the mother's dietary intake in children ages 2-5 years in this research included with a high dietary intake of nutrients. This is because the mothers feel has an obligation to be able to take care of their children properly by providing sufficient and nourishing nutrients on to their children in order not easily experienced health problems especially during development and disorders growth. While on a mother who delivers food intake in low category happened because they still do not have an understanding of the need of proper nutrition for children and also how to cultivate children's meals so that the child does not feel bored with the food menu is served. Food intake provided by the mother of a toddler whom a lot of feeding animal protein such as eggs, meat and vegetable proteins like tempet and tofu. Foods that contain fat are also provided by the mother as the mother provides the food menu soups or bersantan. Good food intake will affect the occurrence of stunting on toddler especially in children ages 2-5 years. Good food intake will meet the needs of child nutrition on growth period so with important nutrients that satisfy at the time periods of growth. The consumption of protein, iron, and zinc also contribute over stunting incident. Protein functions as a shaper of a new network in the growth and development of the body, and also maintain and improve the resilience of the child's body. 
B. Analyze the effect of a history of Infections Against Gen. Stunting in Children Ages 2-5 years in the working area Pustu Kedung Lengkong Clinics Dlanggu Mojokerto

Based on the results obtained by infection history data the majority of respondents have never suffered from infectious diseases as much as 58 respondents (58\%) and suffering from infectious diseases as much as 42 respondents (42\%). Infectious diseases among other children suffered upper respiratory tract as much as 23 children (54.7\%), typhoid fever as many as 12 children (28.6\%), gastroenteritis as much as 5 children (11.9\%), and stomatitis by as much as 1 child (2.4\%). Based on the test results sperman rho between a history of infection with stunting incident demonstrates the significance value $=0.000<0.05$ so that $\mathrm{H} 1$ accepted it's means there is a connection between a history of infection with stunting incident.

The presence of infectious diseases will make things worse if there is a lack of nutritional intake. Toddlers with less nutrition will more easily exposed to infectious diseases. Infectious diseases will join adds to the need for nutrients to aid resistance to the disease itself. Fulfillment of nutrients which is in compliance with the requirements but infectious diseases suffered is not addressed it will not be able to improve the status of health and nutritional status of older toddlers. For it is handling against infectious diseases suffered as early as possible will help the improvement of nutrition with diiimbangi fulfillment of the intake that fits the needs of toddlers (Bappenas, RI, 2013). Microbes as living creatures would of course like to survive with the way the breed at a reservoir that fits well and is able to find new reservoirs by means of switch or spread. The dissemination of microbial pathogens is certainly highly detrimental for people who are in a State of pain (sufferers). A healthy person will become sick and people who are sick and are in the process of healing will earn "extra burden" of the spread of these pathogenic microbes (Darmadi, 2008).

According to the researchers these results indicate that most respondents have never suffered from infectious diseases such as respiratory, typoid, and other infeski diseases. This occurs because the mom trying to keep their children's health by providing sufficient and appropriate nutrients so it can improve the child's immune system primarily on situations or erratic weather conditions so that the child is not an easy experience the infection. Because mothers assume if the easy child hurt when growth will affect the process of growth and development of the child. Actions taken the mother in keeping children's health include the mother delivers food on a high nutritious son so it can boost immunity or ekebalan the body of a child and is not susceptible to the disease, in addition the mother trying to keep the cleanliness of the environment in order to be able to support in the prevention of the spread of the disease because the bacteria or other germs, so children rarely experience the infectious diseases such as respiratory, thypoid, gastroenteritis, or stomatitis. The existence of a history of infectious diseases experienced growth period mainly on the sat at age 2-5 years will affect the occurrence of stunting, this occurs because the child who easily pain they are experiencing disruption in fulfillment of nutrition caused not want or decline your appetite so that nutrients are not being met in adekuat and may inhibit the formation of tissue ultimately inhibit the growth of children.

C. Analyse the influence of Food Availability Against the incidence of Stunting in Children Ages 2-5 years in the working area Pustu Kedung Lengkong Clinics Dlanggu Mojokerto

Based on the availability of family food shows that most families have the availability of good food as much as 64 respondents (64\%). Based on spearman rho between test results of food availability with stunting incident shows the significance value $=0.000<0,05$ so that $\mathrm{H} 1$ accepted it's means there is a relationship between food availability with stunting incident.

Most of stunting in Indonesia is caused by a deficiency of calories and protein. Maybe the calories is enough, but the food is not quality. In addition, most dietary error is given at the time of granting MPASI (food companion breast milk). Many mothers giving complementary foods BREAST MILK only as vegetables or foods containing flour, such as grain or brown rice protein, whereas only obtained from carrots, broccoli or DAB the tofu and tempe. Whereas, if it fulfills the nutritional balance, children obviously no longer need supplements. The recommended protein during MPASI is animal protein, such as meat, milk, eggs (Sik Asik, 2011). The fulfillment of the needs of the food should not only emphasized on the quantity, but also pay attention to the quality, including the food diversity and nutritional balance. The diverse food consumption is very important because the body requires 45 types of nutrients that can be obtained from different types of food and 
drinks. Until today there is no one type of food that can satisfy all the needs of those nutrients. The diversity and balance of food consumption on a family level will determine the quality of consumption on the level region, whether district/city, provincial, and national. The quality of the food consumption of the present inhabitants of the region (macro) this is reflected in the food Patterns with a score of hope (PPH). While at the level of families and individuals, food intake according to principles of food consumption is Varied, nutritious and Balanced Safely (B2SA) to meet the needs of nutrients can be found by conducting an assessment of food consumption, through counting approach serving (Kemenpan Food Security Agency, 2015).

The results of this study showed that the respondents already had enough good food availability. Food availability that exist at the time a researcher doing the observations of the respondents include food groups grains like rice are still many respondents who provide food on the golonggan, animal food such as eggs nearly the whole of the respondents have supplies of eggs, in the oils and fats showed most respondents had a stockpile of oil and fat in the form of coconut milk so that well enough to be consumed within a few days to future. At the nuts-nuts show almost all of the respondents had a pretty much stock, a form of food in this category include temped an know the most widely found. On the rare tubers respondents who have stock on these foodstuffs. For food in the sugar nearly all respondents had stocks of sugar which is still a lot and enough supplies for a few days. The availability of enough food this happens because it is based on the desire of parents especially mothers to be able to meet the nutritional needs of their children so as not to experience problems or disorders on the health issues surrounding the disorder mainly lack nutrition. With the availability of good food so respondents can meet the nutritional needs of the entire family with good anyway and can maintain the health of the entire family and especially on toddler respondents can stimulate the growth and development of toddlers optimally.

\section{Identify the influence of events Parenting Stunting in Children Ages 2-5 years in the working area Pustu Kedung Lengkong Clinics Dlanggu Mojokerto}

Based on parenting nutrition obtained that parents provide nutrition parenting well enough as much as 51 respondents (51\%). Based on the test results of the spearman rho between parenting nutrition with stunting incident shows the significance value $=0.00<0.05$ so that $\mathrm{H} 1$ accepted it's means there is a connection between nutrition parenting with stunting incident.

Parenting is the fulfillment of physical and biomedical needs. This parenting including food and nutrition, basic sanitation, immunization, weighing, treatment, Board/decent settlement, individual hygiene, environmental sanitation, clothing and recreation. Adequate parenting in infants is the fulfillment of the needs of biomedical and physical child fulfilled optimally. This is done through the giving of good nutrition in the form of breast feeding, complementary feeding of BREAST MILK on time and its shape, continue breast-feeding until the child from 2 years, mothers have enough time caring for infants, immunization and growth monitoring through the activity of weighing (Soekirman in Yusnidaryani, 2009). Karyadi (1985) in Adriana (2013) defines parenting parenting practices eat as applied by the mother of the child with regard to the ways and situations. In addition to meals, parenting parenting mom-owned health participated and influenced the health status of toddlers in which indirectly affect the nutritional status of the toddlers. In the flowergrowing children, the role of mother was dominant for nurturing and educating children in order to grow and develop into a quality kid. Parenting toddler eat at relating to eating habits that have been implanted since the beginning of human growth.

The results of this study indicate that the respondent seeks to provide the best for parenting their children primarily about fulfillment of nutrients during growth so that children are not subjected to interference in that period. This is because the mother had been bahwsannya with sufficient nutrition intake during the growth, then the child will not experience failure of growth or development. Parenting given mother in toddlers is mainly about nurturing nutrition has a significant role in preventing the occurrence of stunting on toddlers because feeding on toddlers is entirely governed by his mother. Mother with good parenting will tend to have a toddler with a better nutritional status than mothers with parenting. But in this study mother with good parenting there is also a toddler who suffered this Thing could be stunting because although good mothers parenting, on families with less pereknomian or less income there are limitations in the meet daily needs so as not to affect the mother's parenting issues stunting. Given the mother's parenting parenting particularly about 
nutrition will help the process of growth is running optimally. The existence of proper parenting parents can meet the nutritional kebtuhan and adekuat so that children can grow and develop in accordance with the age of the child.

\section{E. Identify the predominant Factors that influence the incidence of Stunting in Children Ages 2- 5 years in the working area Pustu Kedung Lengkong Clinics Dlanggu Mojokerto}

Based on the results of the analysis show that unison farmed ingredients independent variable affect simultaneously or with a stunting incident, indicated by the value of the overall percentage of 78 meaning independent variable can influence the second variable of $78 \%$. The results of this research show that simultaneously or together independent variables can affect the occurrence of the dependent variable.

Based on the results of partial or in each independent variable influences the incidence of stunting, indicated by the value of the wald on food intake amounted to 5.525 with significance and value of 0.019 wald 9.253 of infectious diseases with the significance of 0.002 , wald on the availability of food of 7.073 with significance and value of 0.008 wald on parenting of 5.377 with significance of 0.020 . The results of this research show that partially or alone - its own independent variable may affect the occurrence of the dependent variables because the value significance $<0.05$.

According to Kemenkes (2012), children who experience stunting due to the low nutrient intake and disease recurrence due to the unhealthy environment. Chronic nutritional problems in toddlers can be caused due to the intake of nutrients that are lacking in a long period of time because of family or parents do not know or have not provided the appropriate foods with nutritional needs of children. According to Supariasa et al (2012) State environmental sanitation is lacking both allow the occurrence of different types of the disease include diarrhea, kecacingan, and infections of the digestive tract. If the child is suffering from a gastrointestinal infection, the absorption of nutrient substances be bothered calling babkan shortage of nutrients. Someone lack nutrients will be susceptible to the disease, and growth will be interrupted.

The results of this research show the food intake, a history of infections, food availability and parenting nutrition can affect the occurrence of stunting in children ages 2-5 years. The influence of all factors that causes as much as $78 \%$ of occurrence of stunting on toddlers. However, based on the partially test shows the value of the most high is wald of infectious diseases. So it can be declared of infectious diseases is the dominant factor affecting the occurrence of stunting on this research. This happens because although children obtain the intake of nutrients that food availability is quite good, quite good juuga respondents however if the child frequently experienced infectious disease then this will decrease the frequency of food children because children's eating nfasu According to so that nutrients are not absorbed optimally and fulfillment needs nutrients not terjasi perfectly so that it can interfere with your child's growth.

\section{CONCLUSION}

Food intake on toddlers ages 2-5 years in the region of Pustu Kedung Lengkong Dlanggu Public Heatlh Center Mojokerto is mostly high nutrition as much as 58 respondents (58\%)

A history of infection in toddlers aged 2-5 years in the region of Pustu Kedung Lengkong Dlanggu Public Heatlh Center Mojokerto most respondents have never suffered from infectious diseases as much as 58 respondents $(58 \%)$

Food availability on toddlers ages 2-5 years in the region of Pustu Kedung Lengkong Dlanggu Public Heatlh Center Mojokerto most families have the availability of good food as much as 64 respondents (64\%).

Parenting toddler age on nutrition 2-5 years in the region of Pustu Kedung Lengkong Dlanggu Public Heatlh Center Mojokerto mostly provide nutrition parenting well enough as much as 51 respondents $(51 \%)$.

The incidence of stunting in children ages 2-5 years $i$ in the region of Pustu Kedung Lengkong Dlanggu Public Heatlh Center Mojokerto most respondents do not experience stunting under normal conditions or as many as 61 respondents $(61 \%)$.

There are influences between food intake with incidence of stunting in the region of Pustu Kedung Lengkong Dlanggu Public Heatlh Center Mojokerto p value $=0.006<0.05$ 
There are influences between infection with stunting incident history in the region of Pustu Kedung Lengkong Dlanggu Public Heatlh Center Mojokerto p value $=0.000<0.05$

There are influences between food availability with stunting in the region of Pustu Kedung Lengkong Dlanggu Public Heatlh Center Mojokerto p value $=0.000<0.05$

There are influences between parenting nutrition with stunting in the region of Pustu Kedung Lengkong Dlanggu Public Heatlh Center Mojokerto p value $=0.000<0.05$

The predominant factors that influence the incidence of stunting is a history of infection in the region of Pustu Kedung Lengkong Dlanggu Public Heatlh Center Mojokerto

\section{REFERENCE}

Adriani. (2013). Pola Asuh Makan Pada Balita Dengan Status Gizi Kurang Di Jawa Timur, Jawa Tengah Dan Kalimantan Tengah, Tahun 2011. Buletin Penelitian Sistem Kesehatan - Vol. 16 No. 2 April 2013.

Anisa, P. Faktor-faktor yang Berhubungan dengan Kejadian Stunting pada Balita Usia 25-60 bulan di Kelurahan Kalibaru Depok Tahun 2011. Depok: Universitas Andalas.

Anshori, H., A. (2013). Faktor Resiko Kejadian Stunting pada Anak Usia 12-24 Bulan (Studi di Kecamatan Semarang Timur). Journal of Nutrition College.

Aridiyah. (2015). Faktor-Faktor yang Mempengaruhi Kejadian Stunting pada Anak Balita di Wilayah Pedesaan dan Perkotaan. e-Jurnal Pustaka Kesehatan 3(1): 163-170.

Arikunto, Suharsini. (2010). Prosedur Penelitian: Suatu Pendekatan Praktek. Jakarta: Rineka Cipta.

Badan Ketahanan Pangan. (2015). Panduang Perhitungan Pola Pangan Harapan (PPH). Jakarta: Kementrian Pertanian.

Hadi, H. (2011). Beban Ganda Masalah Gizi dan Implikasinya Terhadap Kebijakan Pembangunan Kesehatan Nasional. Yogyakarta: FKUGM.

Hidayat. (2010). Metodologi Penelitian Kesehatan. Jakarta: Rineka Cipta.

Kemenkes. (2012). Panduan Penggunaan Kartu Menuju Sehat (KMS) Balita bagi Petugas Kesehatan. Jakarta: Direktorat Gizi Masyarakat.

Kemenkes. (2013). Penilaian Status Gizi Anak. Jakarta: Kementrian Kesehatan RI.

Kemenkes. (2018). Infodatin Situasi Gizi. Jakarta: Balitbangkes RI.

Kementrian Kesehatan Republik Indonesia (2010). Pedoman gizi seimbang. Jakarta: kementrian Kesehatan Republik Indonesia.

Mardini, K., W. (2014). Faktor Resiko Pendek Pada Anak. Bali: Biomedik Univesitas Udayana.

Meilyasari, \& Isnawati. (2014). Faktor Risiko Kejadian Stunting Pada Balita Usia 12 Bulan Di Desapurwokerto Kecamatan Patebon, Kabupaten Kendal. Artikel Ilmiah, Universitas Diponegoro.

Ngaisyah. (2017). Keterkaitan Pola Pangan Harapan (Pph) dengan Kejadian Stunting Pada Balita. Jurnal Kedokteran dan Kesehatan, Vol.13, No. 1, Januari 2017.

Ni'mah \& Nadhioh. (2015). Faktor yang berhubungan dengan stunting pada balita. Media Gizi Indonesia, Vol. 10, No. 1 Januari-Juni 2015. 
Nursalam. (2013). Konsep dan Penerapan Metodologi Penelitian Ilmu Keperawatan. Jakarta: Salemba Medika.

Proverawati, A., \& Kusuma, E., W. (2011). Ilmu Gizi untuk Keperawatan dan Gizi Kesehatan. Yogyakarta: Nuha Medika.

Riyadi, H. (2013). Metode Penilaian Status Gizi secara Antropometri. Bogor: Fakultas Ekologi Manusia. Institut Pertanian Bogor.

Syafiq, Ahmad. (2012). Tinjauan Atas Kesehatan dan Gizi Anak usia dini. Jakarta: BAPPENAS RI

WHO. (2010). Stunting Policy Brief. WHO Press: Geneva.

World Health Organization. World Health Statistics 2017. Geneva: WHO Press.

Dewana, Z., Fikadu, T., Facha, W., \& Mekonnen, N. (2017). Prevalence and Predictors among Children of Age between 24 to 59 Months in Butajira Town and Surrounding District, Gurage Zone, Southern Ethiopia. Health Science Journal. Vol. 11 No 4 